\title{
吹田市における浄化槽污泥処理の現状と 施設整備計画時における検討課題の要点
}

西田 節 雄 ${ }^{*}$

\section{1.はじめに}

今日の我が国におけるし尿処理技術にあっては，こ れまでにおけるし尿処理事業等に関与された各界の関 係者各位の，処理技術の研究や提言，実験による技術 究明等のたゆみない積み重ねを以て, 安定的な処理技 術の段階にあると思う。

しかし，各自治体における浄化槽污泥の処理計画を 含めた施設整備計画に当たっては，それぞれの自治体 が持っている整備計画に係わる諸条件の課題をクリアー されて, 施設の建設をされたことと思考する.

従って, 何のし尿処理方法が多角的に考查して合理 的処理方法といえるのか, その物の見方と受け取り方 で評価が大きく違う。しかるに，し尿処理あるいは， 下水污泥処理技術にあっては，今後，まだまだ研究を 要する課題であると考えている.

そこで, 昭和44年以来, 今日に瓦ってし尿処理事業 の実務に係わってまいり，その間，己れなりに学び得 ることができた事柄を基盤に，本市における浄化槽污 泥処理の現状と, 施設整備計画時における主な課題と 検討結果の要点を紹介することとする.

\section{2. し尿処理施設の沿革概要}

本市におけるし尿処理施設整備事業計画は，昭和37 年に化学処理方式による処理能力 $130 \mathrm{k} \ell /$ 日の処理施 設竣工に始まり, 続いて昭和41年に, 処理人口増加傾 向の事由で, 施設処理能力を $180 \mathrm{k} \ell /$ 日に増設し，さ らに施設機能の老朽化による処理効率の低下, 法改正 による浄化槽污泥の受け入れ処理対策等の事由から， 昭和48年度に，し尿処理事業の抜本的な見直し事業計 画の基本方針を策定した後，昭和51年度に，施設の一 部撤去改造工事を実施し，図一 1 上部に示すように処

* 吹田市環境部化学処理場辰

Setuo NISHIDA
理能力 $180 \mathrm{k} \ell /$ 日（浄化槽污泥混合処理量は生し尿量 の $10 〜 15 \%$ 以内）の現有し尿前処理施設竣工を行なう. 次に, 単独浄化槽污泥の全量受け入れ処理計画と, 浄 化槽污泥脱水処理試験の実施計画に対応するという事 由により, 昭和 57 年度に, 大阪府の補助事業認可を受 けて, 浄化槽污泥用の一部除渣処理設備工事を先行実 施した後, 昭和59年度より旧污泥処理設備の撤去等の, 改造工事を合せ施して，3 ケ年事業（国の補助認可事 業）計画で，図一 1 下部に示すように，処理能力 125 $\mathrm{k} \ell /$ 日の浄化槽污泥処理施設を昭和 61 年 5 月末に完成 させる運びとなり，今日に至る。

\section{3. 施設整備計画時における課題と検討結果 の要点}

他の自治体においても，本市と同様な検討課題があっ たことと思考するが，これから述べる本市の検討結果 の事例が, 今後さらに下水道普及率が高く推移する過 程，あるいは施設の増改造計画を必要とする自治体に あっては，何等かの参考になるのではないかと考え， また本市では, 図一 1 に示すとおり, 二次処理, 高度 処理設備等を設置していない. 故に, その理由を語ら ずに本市の処理事業の現状のみを述べても，無意味な ことではないかと判断し，さらには，ここに述べる検 討結果の事例が広義に解して「一つ」の処理工程，処 理技術ではないかと理解されれば，幸いなことと思考 し，本機会に敢えて報告することとした。

\section{1 主な課題の要旨}

下記に述べる課題は，昭和44年頃の旧化学処理施設 から現有処理施設整備計画に伴う諸条件である。

(1)今後（昭和45年以降）における処理技術調査研究, 施設の維持管理と設計施工等の技術体制強化.

(2)施設敷地面積が，2,443 $\mathrm{m}^{2}$ と狭小で，施設に隣接 する用地には，すでに他施設が設置されており，敷地 の拡大計画は困難. 故に現有敷地内での, 構造指針要 
綱に基づく施設の増改造及び更新工事（国の補助対象 事業）計画は, 物理的に判断して不可能.

(3)前述(2)の事情が故に，新規場所に施設の更新事業 計画を実施する場合，その計画用地に係わる都市計画 決定指導基準が，処理能力 $10 \mathrm{k} \ell /$ 日当たりに対して 1,500 $\mathrm{m}^{2}$ となっており，仮に，その基準に応じて処理

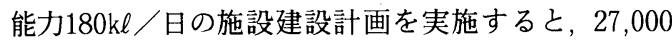
$\mathrm{m}^{2}$ という広大な用地確保が必要条件となる。

(4)下水道普及率の今後推移と, 下水道未普及地域に おける民間企業の宅地開発等による浄化槽設備の設置 状況之処理人口の今後推移等を, 何様に推定し, 今後 のし尿処理事業計画に当てはめるのか.

(5) し尿と浄化槽污泥の混合処理技術の調査研究 (本 市調べでは，昭和56年頃までは，確固たる処理処分方 法はなかったと考える).さらには浄化槽污泥の年間 排出量と污泥質, 清掃作業状況の実態等々の，基礎的 な調査の実施方法のあり方.

以上, 当初施設にあっては過酷な状況であった.

\section{3 . 2 主な課題の検討結果の要点}

前述，3．1 の課題をクリアーするため，本市では， 次のような観点之過程を以て検討を行なった.

（）前述，3.1の(1)の課題

「一人の意見は一人の考えで，何事む進歩すること なし」「いかに立派な家を建てても，そこに住む者の 考えで, 家庭は良くも悪くもなる」という自らの格言 を関係上司に伺い, 処理施設の担当技術職員を 3 名か ら6名に増員配置することを先決する。

() 前述, 3.1 の(2)(3)(4)の課題

物理的に不可能に近いことは実施できない。 また， 新規場所での施設建設計画は，他に適地を容易に確保 することが困難. 仮に，他に計画用地が確保できると しても，し尿処理事業の最終目的は，下水道整備事業 内にあるという事実事項と，し尿処理事業は，下水道 普及率の推移に伴って斜陽的な事業となることは明白 な事実という事項，さらに本市の下水道普及率及び下 水道整備事業の現状と今後計画等々を考虑して, この 事業計画を検討するならば，暫定的な事業であるし尿 処理事業計画に多額の用地購入費，建設費等を投資す ることは，一般的に判断すると，二重投資的な条件を 包括した非合理な事業計画である.

また, 施設完成後の維持管理運営に際しても, 将来 的には，処理量の減少化に伴い，施設処理能力に余裕 が生じてくるが, 他方, 余白的あるいは無䭾な処理施 設規模の状態で，施設の管理運営を行なう結果となり， $\mathrm{k} \ell$ 当たりの処理経費に占める人件費の割合が，年次的 に高く推移する. 従って, それがために, 定量的な負 荷処理プロセスを基準に稼働している処理施設状況で， 処理量の減少推移に応じて容易に見直し（減員）計画 が実施できるのか.さらには，必ず必要とする施設撤 去費が割高になる等々の，已むを得ないアンバランス な諸事情が生じてくると考えた場合，新規場所での施 設整備計画は好ましくないと判断する.

そこで，本市では，以上までの検討事項を考慮する とともに, 一方では, 今後の処理施設整備計画の方向 づけにあっては「水処理設備は下水処理場にある」 「污泥焼却設備は本市ごみ処理工場にある」という物 の見方の観点から, 二次処理, 污泥焼却設備等の設計 計画はしない（建設計画する敷地が無い）と決定した 後, 下水道整備事業の現状と今後計画との整合調整を 行ない，何等かの方法で，し尿と浄化槽污泥の全量を， 下水道流注処理できる技術の調査研究を行なって，そ れを実現可能とすることが, 本市にあっては, これら の課題と問題点を一括して解決できる唯一の得策であ ると判断し, その処理方法を, 今後の事業計画の基本 方針と決定する.

(0) 前述，3．1 (5)の課題と，し尿及び浄化槽污泥の

下水流注処理方法の技術検討について

汲み取りし尿之净化槽污泥の性状は, 端的に表現す るならば,「生きた污泥（処理プロセスが安定）と死 に污泥（定量的負荷処理プロセスの効率的な処理技術 の究明困難)」の関係にあるという観点から，従来か ら行なっている安定したし尿処理プロセスを，敢えて 改革してまで早期に混合処理計画することは, 処理負 荷的に好ましいことではないと判断する

そこで，本市にあっては幸いにも，下水処理場にお いてかなりの余裕処理能力があることが判明したので, 「下水道の未普及地域にあっては，下水道管がないが 故に，水洗便所化ができない」それならば「し尿収集 車両は，移動式下水道管であり，乙尿処理場において は，集合式大型水洗便所を設置し，し尿を下水道に流 せばよい」という物の見方をし，しかるに，下水処理 プロセスを侵すことのない処理技術の調査研究を行なっ て, 現有し尿前処理施設の事業計画を策定した。

続いて, 浄化槽污泥の下水道流注処理方法の技術検 討に当たっては, 先進都市の処理施設視察調査, 浄化 槽污泥の性状分析, 浄化槽設備の清掃作業状況の実態 等の，事前調査を行ない，その処理方法について，い ろいろと模索検討を行なった結果, 浄化槽污泥とは 
「すでに生物処理された濃縮污泥である」「搬入計画 污泥の質及び濃度の変動が激しい」「下水処理場にお ける固形物量負荷が大きくなる」等から，すでに何等 かの方法で生物処理された污泥を, 先のし尿処理方法 と同様な方法で長期的に下水道流注することは，下水 処理場の処理プロセスを考查すると，処理技術的に好 ましい処理方法ではないと判断する。

そこで本市では，下水処理場における水処理負荷及 び水処理経費の負担を最小限にするという観点から 「し尿処理場へ搬入された浄化槽污泥は，搬入された “量”を以て下水処理場へ搬送する」という物の見方 を行なって，浄化槽污泥処理方法は，直接的に固液分 離し，分離液は下水処理場へ, 脱水污泥は「生ごみは 燃える．污泥む生ごみより良好な状態にすれば燃える」 という観点から，焼却炉内でクリンカ状にならない乾 燥処理方法の技術調查を行なって,ごみ処理工場へ搬 送処分するという事業計画方針を決定する。

しかるに，この事業計画の実施設計に当たっては， 何様な固液分離方法が本市にとって最適であるのか, その処理技術の調査研明に際し，先ず処理施設建設プ ラントメーカー 130 社余りに互って, その処理方法に ついての基本設計仕様の照会依頼をし，回答のあった 設計案を，それぞれ技術考查を行ったが，何れのプラ ントメーカーにあっても，し尿処理プロセスに準じた 処理方法で，本市が意図する画期的な浄化槽污泥のみ を, 効率的かつ安定的に固液分離処理できる実証的な 処理プロセスの提案はなかった

しかし，その後において，幸いにも数社のプラント メーカーより, 浄化槽污泥の脱水処理試験を本市施設 内で実施したいという願い出が随時あり，本市はその 旨を都度受理して, 凍結融解法による脱水試験 (1 社) を始めとし，遠心分離機（3 社）ベルトプレス型脱水 機（1社）多重円板型脱水機（1社）による浄化槽污 泥の脱水処理試験を実施した。しかるに，その試験結 果を基に, 現有浄化槽污泥処理施設の基本設計施工書 を作成し得ることができた。

尚, 脱水処理試験の比較検討説明及び乾燥機, 臭気 対策等の検討結果については，限られたスペースを考 慮して省略するが，ここで，本市が採用した多重円板 型脱水機の主な選定理由を，併せて報告する．

（）污泥処理工程には，必ず設けている污泥濃縮処理 設備が不要（脱水機本体の機能が, 万過濃縮から脱 水となっており, 脱水機内に全体量の固形物量が充 填されない限り，污泥は脱水ケーキとして剥離され
ない原理. 故に, 污泥濃度の低い污泥液ほど量的に 多く脱水機へ供給する)

(0) 前述が故に, 何様な污泥質及び污泥濃度の变化が 生じても, 脱水ケーキ（常時， $\fallingdotseq 55 \mathrm{~mm}$ 厚）の剥離性 は全く支障がない.

（）運転操作が容易で，始動後は，運転停止時以外は 無人化が可能で日常監視業務が容易，乃布を使用し ていないので, 目詰り，ろ布張り替え作業が不要で 洗浄水も少ない等で, 保守管理が容易である等.

\section{4. 浄化槽污泥処理工程と運転方法の概要}

本市の処理方法は，前述のとおり，污泥濃縮処理， 2 次処理, 高度処理, 污泥焼却等の処理工程を除いて, 図一 1 ，図一 2 に示すように，高分子凝集剂を使用し て浄化槽污泥の質的改良を行ない，直接的に固液分離 する処理方式（処理能力，施設規摸等については, 図一 2 に示すとおり) である.

即ち, 搬入された浄化槽污泥 (以下, 污泥という) は，通常はNNo. 2 投入口より沈砂処理後, NNo. 2 受入槽 から破砕処理されて, ドラムスクリーンで除渣処理さ れ後,一旦第 1 貯留槽に眝留される.

一方，搬入された污泥の污泥濃度が極端に高い場合 之, 浄化槽設備加ら下水道へ切替工事に伴う污泥排出 時, 浄化槽設備の清掃作業の重複等で, 日量搬入量が

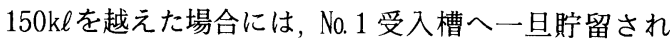
た後, 濃度及び量の均等化を図るため, 処理状況に応 じて，調整されて沈砂槽へ圧送される。

第 1 貯留槽に眝留された除渣污泥は, 後処理工程の 脱水機のろ体円板（S U S 304. $0.3 \mathrm{~mm}$ と $0.8 \mathrm{~mm}$ 厚）の 耐久性を高めるため, サンドセパレーターでさらに細 砂を除去して第 2 貯留槽へ圧送貯留される（但し，圧 送作業は，均等化されている第 2 貯留槽の先き送り除 渣污泥の質及び污泥濃度を維持するため, 脱水機の運 転停止後に行なう).

第 2 貯留槽に貯留された除渣污泥は, 脱水機の運転 始動 2 時間前から脱水機が運転停止するまでの間，ポ ンプ攪汼（曝気粯拌すると, 脱水ケーキ水分が高くな る）を行ない，常に質と污泥濃度の均等化を保った状 態で凝集混和槽へ送り，アニオン系，カチオン系の高 分子凝集剤を添加して質的改良された後, 脱水機で固 液分離される。

固液分離された脱水污泥は，一旦ホッパーに貯留さ れた後, 後処理（本市ごみ処理工場での焼却処分）工 程の燃烤効率を高めるため, 低温乾燥機へ定量的（設 


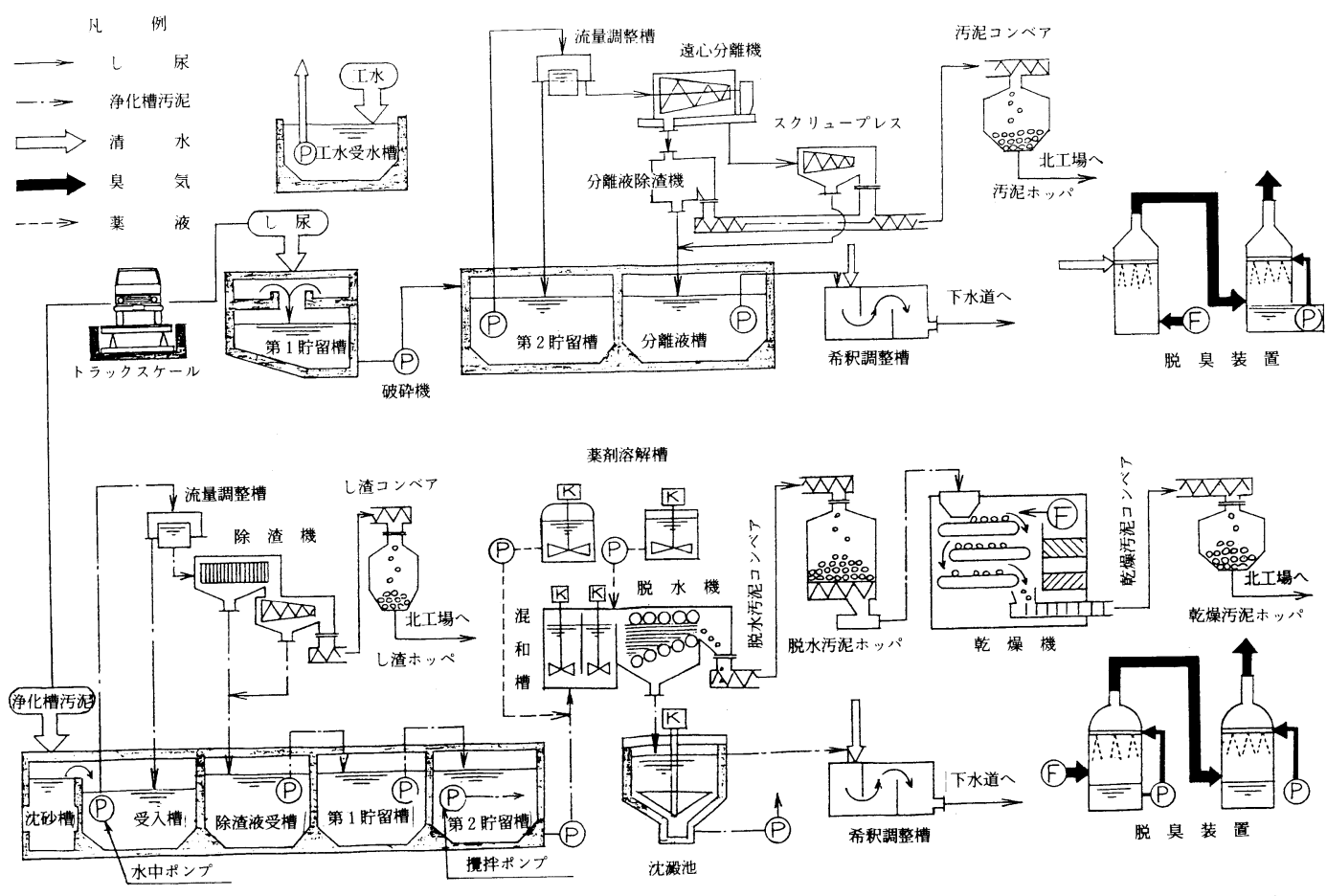

図-1 処理工程概要図

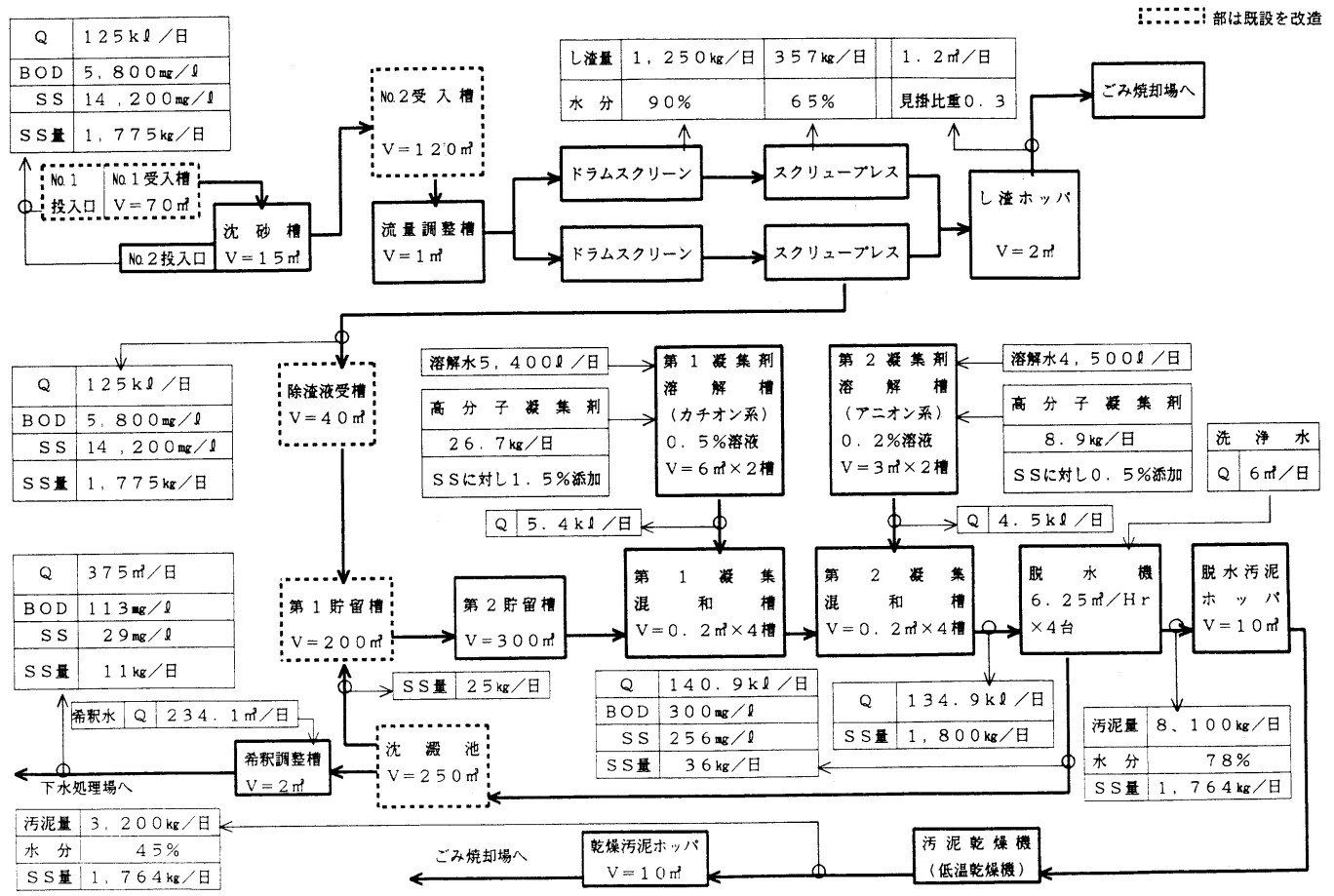

図-2 施設設計規模及び物質収支計算図 
計基準時間 $=20$ 時間）に送られて乾燥（乾燥ヶーキの 形状, 長さ $\fallingdotseq 4 \mathrm{~cm}$, 径 $\fallingdotseq 6 \mathrm{~mm}$ 角）処理された後, ごみ 処理工場入搬送処分される.

分離液は，沈澱池を経て工業用水で 3 倍稀釈（曝気 槽へ直圧送する場合は無稀釈でよい，また沈汼処理も 不要, 本市は臭気対策としている）されて, 下水処理 場の流入原水沈砂池へ流注処理される.

ついでに，本市のし尿処理工程を簡単に紹介する。 生し尿を破砕処理した後, 直接的に遠心分離機で前処 理（固液分離）を行ない, 分離液は施設より $350 \mathrm{~m}$ 先 の幹線下水道へ，約30倍稀釈 (臭気対策も考慮する)

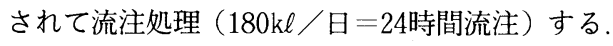

（流注水質基本設計値 $=$ B O D , S S とも $300 \mathrm{mg} / \ell$ 以下, 実績値 $=$ B O D $244 \mathrm{mg} / \ell$, S S 85mg $/ \ell$.)

固形物のし渣は，スクリュープレスで水分 $65 \%$ 以下 に処理された後, 先の処理工程と同様に, ごみ処理工 場へ搬送処分する。

\subsection{3 年度, 净化槽污泥処理実績の概要}

浄化槽污泥の排出量, 人口推定は困難な事務処理 のひとつであるので, 処理実績と伴せて, 本市の排出 量及び人口推定の算出様式について, 先ず紹介す る。

63年度における浄化槽污泥の, 年間排出量及び処理 人口の当初推計は, 前年度 9 月末日現在の総人口数か ら，し尿処理及び下水処理人口の実績数を除いて，厚 生省の一人当たりの排出量基準数値 (単独浄化槽污泥 $0.75 \ell /$ 日, 合併浄化槽污泥 $1.2 \ell /$ 日) を用いて, 次 のように，それぞれを推定した。

$\begin{array}{ccl}\text { 単独浄化槽污泥 } & 16,425 \mathrm{k} \ell & (60,000 \text { 人) } \\ \text { 合併浄化槽污泥 } & 17,958 \mathrm{k} \ell & (41,000 \text { 人) } \\ \text { 合 } \quad \text { 計 } & 34,383 \mathrm{k} \ell & (101,000 \text { 人) }\end{array}$

しかし, 処理実績量の数值は, 次のようになった. 単独浄化槽污泥 $18,448.4 \mathrm{k} \ell$ 合併浄化槽污泥 $\left.\begin{array}{r}8,007.6 \mathrm{k} \ell\end{array}\right\}$ 合計 $26,495 \mathrm{k} \ell$ そこで, 以上の数値を比較すると, 推定量と実績量 とに大きな差（特に合併浄化槽污泥）生じた.

この主な要因は, 過去 3 ケ年の調査結果から, 次の ようなことが分かった。

単独浄化槽の清掃作業時に, 余分な洗浄水または, 污水まで排出されていることと, 合併浄化槽（特に, 長時間嚗気式）にあっては，維持管理上，あるいは排

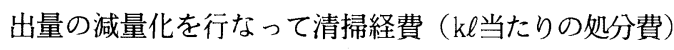
を節減するために，余剩污泥を一旦自前の濃縮槽，貯
留槽等で濃縮した後, 月間 2 回〜 4 回程度に分けて処 理場へ搬入計画される状況が多々あるがため, それぞ れの実績処理量に増減が生じる結果となった。

よって本市では，このような状況と63年度の年間平 均 S S 実績数値が, $14,100 \mathrm{mg} / \ell$ と設計基準値に近い 実態，さらに搬入された合併浄化槽污泥の中にあって は, S S の最大值が39,730mg/ $\ell$, 低い場合でも 15,000 $\mathrm{mg} / \ell \sim 28,000 \mathrm{mg} / \ell$ という実状を考査して, 前述の 一人当たりの排出量基準と, 施設設計時における構造 指針の S S 基準数值 $(11,000 \mathrm{mg} / \ell)$ を用いて, S S の処理実績値から年間排出量と処理人口を, 次のよう に換算推計を行ない，63年度の処理量之処理人口の推 定実績とした。

$\begin{gathered}\text { 年間処理実績量 } \\ (26,495 \mathrm{k} \ell)\end{gathered} \times \frac{\mathrm{S} \mathrm{S} \text { 実績值 } 14,100 \mathrm{mg} / \ell}{\mathrm{S} \mathrm{S} \text { 基準值 } 11,000 \mathrm{mg} / \ell}$

$\fallingdotseq 33,962 \mathrm{k} \ell$ (年間処理実績量) と推定する.

以上の換算推定数に基づき, 次に年度末に調査した 合併浄化槽設置基数及び処理人口の資料を基に,

合併浄化槽の処理人口実績 $=40,381$ 人之推定し， その年間排出量を, 次のように算出した.

$40,381 \times 1.2 \ell /$ 日 $\times 365$ 日 $\fallingdotseq 17,687 \mathrm{k} \ell$ となり，この 数值を, 合併浄化槽污泥の処理実績量と推定する.

さらに単独浄化槽污泥の年間排出量と処理人口を, 次のように按分算出する.

$33,962 \mathrm{k} \ell-17,687 \mathrm{k} \ell=16,275 \mathrm{k} \ell$ となり, この数値を, 単独浄化槽污泥の処理実績量と推定し，その処理人口 実績を, 次のとおり推定した。

$16,275 \mathrm{k} \ell \div 0.75 \ell /$ 日 $\times 365$ 日 $\div 59,435$ 人

故に, 浄化槽処理人口合計実績 $=99,834$ 人となり, 先の当初推計と比較して妥当な処理実績数値となった. また, 以上の換算推定数と当初推計数を考査すると, 次のようなことがいえる.

搬入処理された合併浄化槽污泥の S S 年間平均値は, 単独浄化槽污泥 (9,000mg $/ \ell \sim 12,000 \mathrm{mg} / \ell$ ) の約 2 倍 $(22,000 \mathrm{mg} / \ell \sim 24,300 \mathrm{mg} / \ell)$ と推定すること ができる.

尚，参考までに，図一 3 ，図ー4に示すように，年 間月別毎の搬入量及び濃度の変動状況を報告する.

（）その他, 主な処理実績

$\begin{array}{lll}\text { 日量平均処理量 } & 88.3 \mathrm{k} \ell & \text { (300日平均) } \\ & 113.2 \mathrm{k} \ell & (\mathrm{S} \mathrm{S} \text { 值換算量) } \\ \text { 沈砂排出処分量 } & \fallingdotseq 39 \mathrm{~m}^{3} / \text { 年 } & \\ \text { 脱水污泥含水率 } & 77.5 \% & \text { (年平均值) } \\ \text { 乾燥污泥含水率 } & 43.0 \% & \text { (年平均値) }\end{array}$




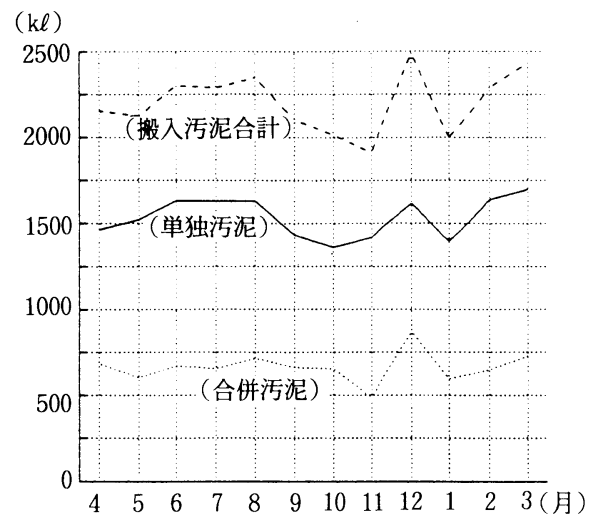

図-3 昭和63年度浄化槽污泥搬入量月別変動状況

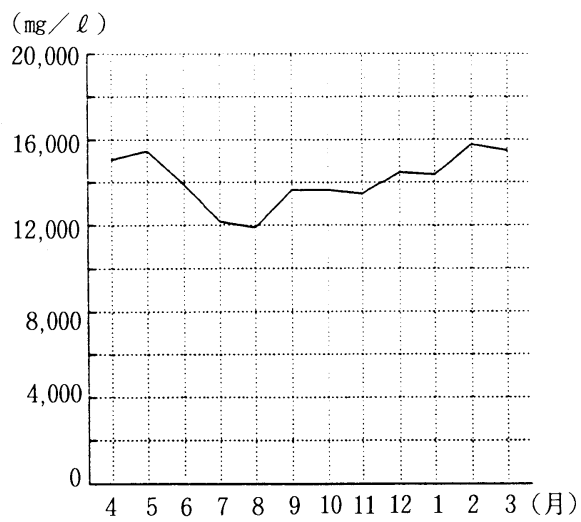

図-4 昭和63年度搬入污泥濃度月別変動状況

乾燥污泥処分量 $\quad 748,160 \mathrm{~kg} /$ 年

下水処理場流注水質 （年平均値）
$\mathrm{P} \quad \mathrm{H} \quad 7.0$
$\mathrm{S} \quad \mathrm{S} 14 \mathrm{mg} / \ell$
C O D 42mg / $\ell$ B OD $131 \mathrm{mg} / \ell$

以上が，水処理工程，污泥焼却工程のない，本市の 浄化槽污泥処理の現状報告です．

\section{6. まと め}

本市の净化槽処理方法は，これまで各分野の関係各 位の長い年月に瓦るご指導，ご理解を以て，画期的と 思考する処理プロセスに示すとおり，次のような成果 を挙げることができたと考える.

(○)施設建設費，維持管理の大幅な節減は申しあげる までもなく, 前述, 搬入污泥の質及び濃度変動が激し い状況下，あるいは下水道普及率の推移に伴うし尿処 理事業の, 年次的縮小合理化計画等が，処理設備の主 要機器の運転稼働時間調整を以て，それぞれ容易に対 処することができる.

(○)後, 施設の増改造及び更新工事計画等を必要之 する従来水処理方式の処理施設にあっては，一考（2 次処理, 高度処理の設計負荷值を容易に軽減すること が可能，その処理設備規模を大幅に縮小化が可能，建 設費の節減が可能等）をもたらす上で，効率的かつ安 定した処理方式の「一つ」である.

従って，3〜4年程前から, 本市が意図とする処理 プロセスと基本的に同様な処理方法が, 数社の企業に よって技術開発されて，あるいは本市への視察を参考 に，すでに施設を建設（増改造）されて現在稼働して いる処理施設は少なくないということを，併せて報告 いたします。

最後に，本市で污泥脱水処理試験を実施された各企 業に対し, 本誌をかりて, 改めて感謝と㧍礼を申しあ げるとともに, 今後の本市における処理事業の課題に 当たっては, し尿処理の稀釈水減量化，処理工程の一 元化を図るため，すでに行なってきたし尿と浄化槽污 泥の混合脱水処理試駼結果を基礎とし，さらに効率的 な処理結果を得る研究に鋭意とりくんでまいり，その 実現化に向けて，今一層の技術究明に精進する所存です．

尚，本報告について，ご意見，ご所見をいただいて， 前進ある論議ができ得るならば，幸いかと思います．

好評発売中

污泥の処理·処分·再資源化

污泥研究年報 1986 1987年版

B 5 判 350 頁（9 ポ二段組） 定価13,000円（干400円）

発行 環境技術研究協会/干530 大阪市北区天満2-1-20 T E L 06-357-7611 